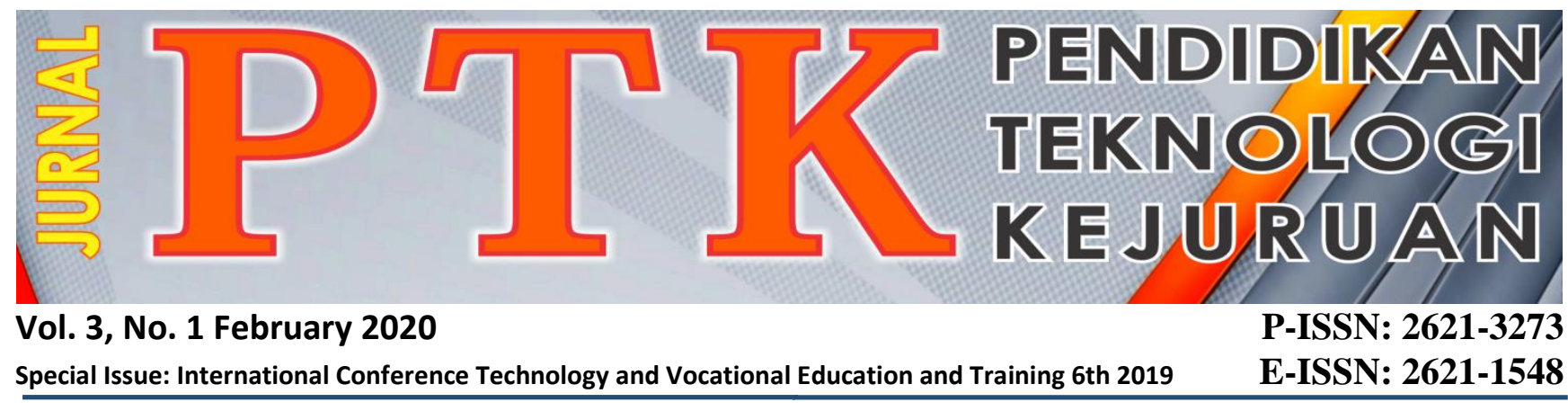

\title{
A NEED ANALYSIS FOR EVALUATION MEDIA DEVELOPMENT OF THE PROJECT-BASED QUIZ CREATOR IN COMPUTER AND BASIC NETWORK SUBJECT
}

\author{
Deni Saputra ${ }^{1}$, Sukardi ${ }^{2}$, Giatman $^{3}$ and Edidas ${ }^{4}$ \\ ${ }^{1}$ Vocational Technology Education, Faculty of Engineering, Universitas Negeri Padang \\ ${ }^{2}$ Faculty of Engineering, Universitas Negeri Padang \\ *Corresponding author, e-mail: adi.dwinko@gmail.com
}

\begin{abstract}
This need analysis research consists of observations and literature studies. This research aims to 1) describe student learning outcomes in the learning process. 2) find the problems faced by students in Computer and Basic Network subject. 3) find Evaluation media solutions needed in conducting the assessment. This research was a descriptive quantitative research. The subjects of this research were 31 students of Grade $X$ TKJ in Vocational High School 2 Lubuk Basung. The data were obtained from questionnaires and analysis through the ADDIE model (Analyze, Design, Development, Implementation, Evaluation) to get conclusions. The results of the research showed that: 1) there were still many students who had not yet reached the Minimum Learning Standard. 2) the learning media used did not make it easy for students to understand the material. 3) the evaluation media used took a long time to get results.
\end{abstract}

Keywords: Need Analysis, Descriptive Quantitative, Evaluation Media, Computer and Basic Networks, Quiz Creator

Copyright $\odot 2020$ JPTK. All rights reserved

\section{INTRODUCTION}

Education is a conscious and planned effort to create an atmosphere of learning and learning process so that students actively develop their potential to have spiritual strength, self-control, personality, intelligence, noble character, and the skills needed by themselves, society, nation and state [1]. The problem that is often encountered in education is low learning outcomes [2]. This problem is faced by students who usually come from students (internal factors) and outside students (external factors) [3].

External factors that affect student learning outcomes are learning media and evaluation media used. The media is an intermediary or introduction to the message from the sender to the recipient of the message [4]. The effectiveness of the media in learning will affect a student's learning outcomes. Besides the dominant evaluation media using a piece of paper does not make students interested, they want a creative evaluation media [5]. Evaluation is a systematic assessment and assesses the relevance of performance and effectiveness goals [6]. However, in its implementation, there are still many evaluation media that have not been good. In preliminary observations, the researchers made at Vocational High School 2 Lubuk Basung, Agam Regency, West Sumatra, Indonesia. Researchers conducted observations of grade X Computer and Network Engineering in Computer and Basic Networks subject.

The use of evaluation media in Computer and Basic Network subject is considered to be less effective and efficient. This is because the evaluation media used still use paper and pencil. In addition, the evaluation results in paper form require a long time to see the completeness of student learning outcomes. This has an impact on the length of time students know the report on the achievement of learning outcomes, such as the results of evaluations in the implementation of practicum making improvements to the hardware in grade $\mathrm{X}$ TKJ 2 which can be seen in table 1 . 
Table. 1. Value of Completeness

\begin{tabular}{|l|l|l|l|}
\hline Class & $\begin{array}{l}\text { Number of } \\
\text { Students }\end{array}$ & Complete & Incomplete \\
\hline X TKJ 2 & 31 & 19 & 12 \\
\hline
\end{tabular}

The results of the evaluation found were $61.29 \%$ from the total of the students of grade X TKJ 2 that were incomplete, so they had to do remedial by doing repairs on computer hardware. This can be seen from the results of the practicum they got according to table 2 .

Table. 2. Value acquisition

\begin{tabular}{|l|l|}
\hline Scores & Number of Students \\
\hline $75-100$ & 20 \\
\hline $51-74$ & 4 \\
\hline$<50$ & 7 \\
\hline
\end{tabular}

The results of the percentage of operating system installation practicum were $35.48 \%$ from 31 students of grade $\mathrm{X}$ TKJ 2 that got scores below the Minimum Learning Criteria $(\mathrm{KBM}=75)$. Thus, applying project-based learning media.is needed to increase the learning outcomes of the students who get low scores. The development of project-based learning media is able to increase students' 'understanding of computer hardware so that learning outcomes can be improved with the support of evaluation media that attract students' attention. The quiz creator evaluation media is able to help teachers to get concrete grades and get the number of values quickly.

Quiz Creator is a well-known software for questions, quizzes or online tests maker, it is easy to use and does not require special expertise in programming to run it. In its use which is very familiar and easy to operate, so it does not require programming skills that are difficult to operate. There are 10 forms of quiz creator software in order to attract students' attention to participate in the evaluation, namely: true/false, multiple choices, multiple responses, fill in the blank, matching, sequence, word bank, click map, short essay, and the blank page. In making the questions on the quiz creator software, users can insert pictures, sounds, videos, formulas, and several other features in order to make it easier for the users to understand the work on making questions. It is also equipped with feedback facilities to find out the response of user answers, test results, change the form of text, create random questions, use user ID and password, and also the attractive appearance. This software can be run by using Adobe Flash Player Software after the questions are designed and stored or published in various forms, namely web, LMS, Exe, Microsoft Word or Microsoft Excel [7].
The development of an online examination system using web-based Wondershare Quiz Creator produces validity, practicality, and effectiveness of assessment, appropriate with the research done [8]. Besides that, it has been proven effective, interesting and valid to have an online exam system feasibility by using multiple-choice questions viewed in terms of validity, practicality, and effectiveness through the development of an online system of multiplechoice questions using the Wondershare quiz creator software, such as the research conducted [9]. The research and development of evaluation media based on e-learning using Wondershare Quiz Creator software in Accounting Subject were also suitable to be used [10]. Based on this, the researchers are interested in conducting research on "The Development of Evaluation Media of The ProjectBased Quiz Creator in Computer and Basic Networks Subject".

\section{METHODOLOGY}

This research was a research and development, which was limited to the need analysis and based on the initial observations in the field and the relevant literature studies. The research subjects were 31 students of grade $\mathrm{X}$ TKJ 2 computer and basic networks subject. The research method used in this research was the descriptive quantitative method. This method describes objectively phenomena and is studied in a quantitatively [11].

The data were obtained from the use of the ADDIE model (Analysis - Design - Development Implement - Evaluate) [12]. Moreover, the initial stage was analyzing the initial data obtained during observation and the need for the improvement of the learning outcomes. The second stage was designing the learning media and evaluation media used. The third stage was developed from the evaluation media that were commonly used into evaluation media that attracted students' attention and got accurate grades. The fourth stage was implementing or applying the results of media design. Finally, the last stage was evaluating with the media provided. From these stages, the problem and the question from the researcher can be solved to get a conclusion.

\section{RESULTS AND DISCUSSION}

From the results of the needs analysis of the evaluation media of the project-based quiz creator to improve computer hardware in computer subjects and basic networks obtained through observation and conducted to 31 students at Vocational High School 2 Lubuk Basung in the Computer and Network Engineering expertise program obtained 
the result of the research which was presented in table 3 below.

Table 3. The Results of needs analysis of the media evaluation for Computer and Basic Networks Subject

\begin{tabular}{|c|c|c|c|}
\hline No & Question analysis & Identification of problems & Conclusion \\
\hline 1 & $\begin{array}{l}\text { Based on the } 31 \text { students who took } \\
\text { part in, } 61.29 \% \text { of them got scores } \\
\text { below the Minimum Learning } \\
\text { Standard }\end{array}$ & $\begin{array}{l}\text { Students have not been able to } \\
\text { understand the material well }\end{array}$ & $\begin{array}{l}\text { Student learning outcomes } \\
\text { are low }\end{array}$ \\
\hline 2 & $\begin{array}{l}\text { Based on the } 31 \text { students who did the } \\
\text { practicum, } 35.48 \% \text { of them had not } \\
\text { yet got scores that fulfilled the } \\
\text { Minimum Learning Standard }\end{array}$ & $\begin{array}{l}\text { Students have not been able to } \\
\text { carry out the practice properly }\end{array}$ & $\begin{array}{l}\text { Achievement of student } \\
\text { practice results is low }\end{array}$ \\
\hline 3 & $\begin{array}{l}\text { Evaluation media used were not yet } \\
\text { technology }\end{array}$ & $\begin{array}{l}\text { Evaluation media still used } \\
\text { paper and pencil }\end{array}$ & $\begin{array}{l}\text { Use interesting evaluation } \\
\text { media }\end{array}$ \\
\hline 4 & Evaluation results took a long time & $\begin{array}{l}\text { Conducting an assessment } \\
\text { manually }\end{array}$ & $\begin{array}{l}\text { Requires a faster evaluation } \\
\text { media in the assessment of } \\
\text { learning outcomes }\end{array}$ \\
\hline
\end{tabular}

The results of the analysis of the media validator, content, and media users of the project-based quiz creator evaluation showed that there were still many student learning outcomes under Minimum Learning Standard (KBM). Thus, it is expected that this research can improve student learning outcomes and get an assessment quickly and validly.

\section{CONCLUSION}

Based on preliminary studies and research results, the expected objectives of this research can be concluded that:

1. There are still many students who have not reached the Minimum Learning Standard (KBM) and do not understand the material.

2. Problems found in learning are the use of instructional media and evaluation media that are not yet creative and validity of the data.

3. The media need to be developed in this research using the quiz creator evaluation media.

\section{REFERENCES}

[1] Pemerintah Indonesia. Undang-Undang Republik Indonesia Nomor 20 Tahun 2003 Tentang Sistem Pendidikan Indonesia.Lembaran RI Tahun 2003 No. 3. Jakarta: Sekretariat Negara. 2003

[2] Sari, M. M., Taufik, T., \& Yusri, Y. Peran Guru Bk/Konselor dan Guru Mata Pelajaran dalam Meningkatkan Motivasi Belajar Siswa yang Memperoleh Hasil Belajar Rendah. Konselor, 3(2), 59-66. 2016

[3] Khafid, M. Faktor-Faktor Yang Mempengaruhi Kesulitan Belajar Akuntansi. Dinamika Pendidikan, 2 (1). 2007.
[4] Arsyad, Azhar. Media Pembelajaran. Jakarta: PT. Raja Garfindo Persada. 2011.

[5] Rachmawati, E. Pengembangan Alat Evaluasi Pembelajaran Berbasis Komputer Dengan Wondeshare Quiz Creator Pada Materi Pajak Penghasilan Pasal 21. Jurnal Pendidikan Akuntansi (JPAK), 2 (2). 2014.

[6] Wakhinuddin S. Evaluasi Program. Padang : Universitas Negeri Padang. 2009.

[7] Hernawati, K. (2009). Membuat Quiz/Evaluasi dengan WonderShare Quiz Creator. On line at http://staff.uny.

id/sites/default/kuswarihernawati-

ssimkom/modulwondershare.

pdf.[diakses tanggal 23 Februari 2015].

[8] Fitri Yani. Pengembangan Sistem Ujian Online Mengunakan Wondershare Quiz Creaotr Berbasis Web Pada Mata Pelajaran TIK. Skripsi tidak diterbitkan. Padang: Universitas Negeri Padang. 2017

[9] Wiji Utomo, D. W. I. Pengembangan Sistem Ujian Online Soal Pilihan Ganda Dengan Menggunakan Software Wondershare Quiz Creator. Inovasi Pendidikan Fisika, 4 (3). 2015.

[10] Rolisca, R. U. C., \& Achadiyah, B. N. Pengembangan Media Evaluasi Pembelajaran Dalam Bentuk Online Berbasis E-Learning Menggunakan Software Wondershare Quiz Creator Dalam Mata Pelajaran Akuntansi SMA Brawijaya Smart School (BSS). Jurnal Pendidikan Akuntansi Indonesia, 12 (2). 2014.

[11] Nana Syaodih Sukmadinata. Metode Penelitian Pendidikan. Bandung: PT. Remaja Rosdakarya. 2010 
[12] Dick, W., and Carey, L. The Systematic Design of Instruction (4th Ed). New York: Haper Collins College Publishers. 1996.

[13] R. Lapisa, I. Basri, M. Milana, and A. Arif, "Review Implementasi Teknologi Informasi dan Komunikasi dalam Kegiatan Pembelajaran: Studi Kasus SMK di Kota Padang Panjang”, JPTK, vol. 2, no. 4, pp. 103109, Nov. 2019

[14] S. Subijanto, "Perceptions of Workplace, Principal, and Productive Teachers on Students' Work Readiness in SMK Negeri 5 Surabaya Indonesia", JPTK, vol. 2, no. 4, pp. 125-133, Nov. 2019.

[15] E. Saputra, W. Wakhinuddin, and F. Rizal, "Pengembangan Media Pembelajaran Elektronik Berbasis Masalah pada Mata Pelajaran Komputer dan Jaringan Dasar", JPTK, vol. 2, no. 2, pp. 39-44, May 2019.

[16] R. Nabawi, N. Jalinus, and S. Syahril, "MEWUJUDKAN TUJUAN PENDIRIAN AKADEMI KOMUNITAS MELALUI PENERAPAN MODEL PROJECT BASED LEARNING", JPTK, vol. 1, no. 2, pp. 51-58, May 2018.

[17] N. Azhar, K. Rukun, and A. Huda, "Analisis Pelatihan Penggunaan Media Pembelajaran CD Interaktif Berbasis Multimedia Dan Modul IPA SD Kelas III di Kecamatan Koto Tangah Kota Padang", JPTK, vol. 2, no. 1, pp. 17-24, Feb. 2019 